УДК 373.3.091.313

DOI https://doi.org/10.24919/2308-4863/34-1-39

Тетяна ВАСЮТІНА, orcid.org/0000-0003-0253-1932 кандидат педагогічних наук, доиент, доцент кафедри педагогіки та методики початкового навчання Національного педагогічного університету імені М. П. Драгоманова (Київ, Украӥна) tetyana.vasyutina@gmail.com

Оксана КОХАНКО, orcid.org/0000-0002-9644-4233 кандидат педагогічних наук, доцент, доиент кафедри педагогіки та методики початкового навчання Національного педагогічного університету імені М. П. Драгоманова

(Київ, Україна) o.g.kohanko@gmail.com

Тетяна ЗОЛОТАРЕНКО, orcid.org/0000-0002-7533-4676

студентка магістратури факультету педагогіки і психології Національного педагогічного університету імені М. П. Драгоманова

(Київ, Україна) zolotarenkotetiana@ukr.net

\title{
МЕТОДИКА ОРГАНІЗАЩЇ̈ ЗАНУРЕНЬ У ПОЧАТКОВІЙ ШКОЛІ ЯК ПРИКЛАД МІЖДИСЦИПЛІНАРНОЇ ІНТЕГРАЦІї В STRЕАМ-ОСВІТІ
}

Тема та зміст статті зумовлені сучасними змінами в освітній системі України та реформами, які активно впроваджуються у шкільну практику. У статті висвітлено проблему реалізації різних рівнів інтегрованого навчання в освітньому проиесі початкової школи, здійснено короткий ретроспективний аналіз розвитку інтеграчії як філософської категорії в освіті, ї̈ типів і видів, методів і засобів. Роз'яснено три підходи до здійснення інтегрованого навчання учнів: мультидисциилінарний, міждисциплінарний (інтердисциплінарний) і трансдисциплінарний. Окреслено важливість багатоваріантності впровадження міждисциплінарної інтеграції у навчання здобувачів освіти, наведено приклади ї̈ результативності через застосування однієї з технологій концентрованого навчання та STREAM-освіти у практиці початкової школи.

Авторами обтрунтовано феномен «занурення» (в сучасному досвіді зустрічається термін "хвильове занурення») як один із давно відомих методів інтегрованого навчання, який розглядається в педагогіиі та психологї крізь призму технологій кониентрованого навчання та проєктної діяльності учнів. Занурення в теорії освітніх технологій (Г. Селевко та інші) представлено у вигляді кількох моделей: сугестивної, двопредметної, тематичної, евристичної (проєктної), занурення в культуру та циклової.

У публікації висвітлено досвід експериментального впровадження хвильового занурення у 2-му класі НУШ на тему «Подорожуємо Україною», метою якого було формування основ громадянської компетентності в учнів (елементарних навичок критичного мислення та знань про права дітей). Це занурення було евристичною (проєктною) моделлю концентрованого навчання, яке позиціонувалося як тривалий інформаційно-прикладний проєкт із підпорядкуванням змісту всіх уроків і позаурочної діяльності STREAM-освіті. На основі одержаних експериментальних результатів зроблено висновок про ефективність занурень $і$ як моделі концентрованого навчання, $i$ як методу успішної міждисииплінарної інтеграції в умовах STREAM-освіти початкової иколи.

Ключові слова: інтеграція, інтегроване навчання, занурення, хвильове занурення, STREAM-освіта, проєкт. 


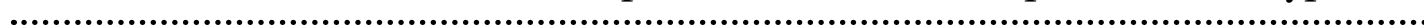

Tetiana VASIUTINA,

orcid.org/0000-0003-0253-1932

Candidate of Pedagogical Sciences, Associate Professor, Associate Professor at the Department of Pedagogy and Methodology of Primary Education National Pedagogical Dragomanov University (Kyiv, Ukraine) tetyana.vasyutina@gmail.com

Oksana KOHANKO, orcid.org/0000-0002-9644-4233

Candidate of Pedagogical Sciences, Associate Professor, Associate Professor at the Department of Pedagogy and Methodology of Primary Education National Pedagogical Dragomanov University, (Kyiv,Ukraine) o.g.kohanko@gmail.com

Tetiana ZOLOTARENKO, orcid.org/0000-0002-7533-4676 Master's Student at the Faculty of Pedagogy and Psychology National Pedagogical Dragomanov University (Kyiv, Ukraine) zolotarenkotetiana@ukr.net

\section{METHODOLOGY OF ORGANIZING IMMERSION IN PRIMARY SCHOOL AS AN EXAMPLE OF INTERDISCIPLINARY INTEGRATION IN STREAM EDUCATION}

The topic and content of the article are due to modern changes in the educational system of Ukraine and reforms that are being actively implemented in school practice. In particular, the problem of implementation of different levels of integrated learning in the educational process of primary school is covered; a brief retrospective analysis of the development of integration as a philosophical category in education, its types and kinds, methods and tools is conducted. Three approaches to the implementation of integrated student learning are explained: multidisciplinary, interdisciplinary and transdisciplinary. The importance of multivariate introduction of interdisciplinary integration in the education of students is outlined, examples of its effectiveness are given through the application of one of the models of technologies of concentrated learning and STREAM education in the practice of primary school.

The authors substantiate the phenomenon of "immersion" (nowadays the term "wave immersion" occurs) as one of the long-known methods of integrated learning, which is considered in pedagogy and psychology through the prism of concentrated learning technologies and project activities of students. Immersion in the theory of educational technologies (H. Selevko and others) is presented in the form of several models: suggestive, two-subject, thematic, heuristic (project), immersion in culture and cyclic.

The publication highlights the experience of experimental implementation of wave immersion in the 2nd grade of NUS on the topic "Traveling Across Ukraine", which aimed to form the foundations of civic competence in students (basic skills of critical thinking and knowledge of children's rights). This immersion was a heuristic (project) model of concentrated learning, positioned as a long-term information-applied project with the subordination of the content of all lessons and extracurricular activities to STREAM education. Based on the obtained experimental results, a conclusion was made about the effectiveness of immersion. It is effective as a model of concentrated learning as well as a method of successful interdisciplinary integration in the STREAM education of primary school.

Key words: integration, integrated learning, immersion, wave immersion, STREAM education, project.

Постановка проблеми. Реформування системи освіти України, запровадження Концепції розвитку природничо-математичної освіти (STEM-освіти) зумовили пошук нового змісту, форм, методів і засобів навчання молодших школярів, які б враховували їхні запити і формували ключові компетентності та наскрізні уміння, передбачені чинним Державним стандартом початкової освіти та Концепцією НУШ. Запровадження як інтегрованих курсів, так і наявність окремих предметів у розкладі зумовили ситуацію, що українському вчителю, який звик реалізову- вати дисциплінарний підхід до навчання протягом багатьох років, доводиться (майже самотужки) розбиратися 3 широкою палітрою видів, підходів та засобів інтегрованого навчання, представлених у численних інтернет-ресурсах і методичних посібниках. У зв'язку з цим ми хочемо поділитися думками щодо досвіду і перспектив запровадження у початковій школі одного 3 методів інтегрованого навчання - занурень як одного зі способів організації освітнього процесу в умовах STEM (STREM, STREAM)-освіти, що вже практикується в закладах освіти України різних ступенів. 
Аналіз досліджень. Вивчення інформаційних джерел, зокрема публікацій Міжнародного освітнього центру INSIGHT, КМДШ, педагогічного досвіду дозволило встановити, що занурення (інколи педагоги називають його хвильовим зануренням) -цеодин із навчальних підходів, який базується на засадах інтеграції та проєктної діяльності і передбачає вивчення предметів у межах однієі теми протягом певного часу (Офіційний, 2019).

Занурення, за задумом педагогів О. Буковської, Л. Фісунова, П. Соколовської, І. Іщук та інших сприятимуть тому, що учні отримають цілісне уявлення про світ, адже вивчають явища 3 точки зору різних наук і вчаться вирішувати реальні проблеми за допомогою знань із різних дисциплін. Досвід їх проведення у закладах приватної форми власності (КМДШ, Академія А+) показав, що хвильові занурення сприяють комплексному сприйняттю i усвідомленню матеріалу, дозволяють урізноманітнити види і форми діяльності учнів, дотримуючись обраної теми (Офіційний, 2019).

Мета статті - 3'ясування сутності поняття «занурення», які саме інтеграційні підходи у ньому представлені, які характеристики вони мають 3 огляду на проєктну діяльність і показати на прикладі, як їх можна організовувати у початкових класах НУШ.

Виклад основного матеріалу. Дослідження базових психологічних джерел дозволило встановити, що поняття «занурення» сягає своїм корінням психодидактики (О. Сергєєнкова, Г. Селевко). Так, у психології метод занурення розглядається як «активний метод навчання 3 використанням елементів релаксації, навіювання та гри. На відміну від інших методів навчання, де основний акцент впливу на учнів припадає на переконання, метод занурення здебільшого спирається на навіювання. Переконання впливають насамперед на людей із розвиненим логічним мисленням, тоді як навіювання ефективне не тільки для таких людей, але й для людей із не досить розвиненим логічним мисленням, якими $є$ учні 1-2 класів початкової школи. Якщо переконання супроводжується помірною критикою з боку того, хто переконує, то навіювання розраховане на некритичне сприйняття повідомлень, у яких щось стверджується або заперечується без доведення» (Метод, 2019: 160). Цей факт, на нашу думку, яскраво ілюструє суть групової роботи з молодшими школярами у проєктній діяльності, зокрема на дослідницькому етапі.

Г. Селевко занурення розглядає крізь призму технології концентрованого навчання, в основу якої покладено такі цільові орієнтації: скорочення розриву між збільшенням обсягу навчальної інформації та обмеженням у часі, передбаченому на його опрацювання; прискорення та інтенсифікація освітнього процесу за рахунок стиснення (концентрації) навчальної інформації; активізація пізнавальних інтересів учнів за рахунок загального бачення перспективи; вироблення швидкості виконання розумових дій (загально-навчальних навичок); цілісне формування якостей особистості, необхідних для прискореного засвоєння матеріалу (концентрація уваги, цілеспрямованість); формування схемного, знакового, символічного, критичного мислення (Селевко, 2006: 489). При цьому автор рекомендує застосовувати групові та індивідуальні організаційні форми навчання, які є ключовими у проєктній діяльності учнів.

У контексті технології концентрованого навчання Г. Селевко розглядає кілька моделей занурень: сугестивна, двопредметна, тематична, евристична (проєктна), занурення у культуру та циклова («конвеєрна», «вахтова») (Селевко, 2006: 495). Так, робота учнів за моделлю сугестивного занурення (В. Мясищев, Д. Узнадзе, Г. Лозанова) забезпечує надзвичайно високу концентрацію уваги і посилення (розкриття) творчих здібностей учнів в умовах інтегрованого вивчення того чи іншого питання (Селевко, 2006: 490).

Аналіз фахової літератури з питань інтеграції, цілісного поєднання знань у систему свідчить, що проблема своєю глибиною сягає в освітній фундаменталізм і розпочинається 3 праць педагогівкласиків Й. Гербарта, Дж. Дьюї, Я. Коменського, Дж. Локка, Й. Песталоцці, Ж.-Ж. Руссо, К. Ушинського. Протягом наступних років думка про інтегроване навчання учнів міцніс, і вже у XX столітті вчителі-новатори активно впроваджують внутрішньо-предметну інтеграцію (Ш. Амонашвілі, П. Ерднієв, С. Лисенкова, В. Сухомлинський, В. Шаталов) та експериментують із міжпредметною (інтегровані уроки, інтегровані навчальні курси) (О. Алексеєнко, Н. Бібік, М. Вашуленко, С. Волокова, Н. Коваль, Л. Кочина, Т. Пушкарьова, О. Савченко, В. Тименко).

Світова практика пропонує три підходи до здійснення інтегрованого навчання учнів: мультидисциплінарний, міждисциплінарний (інтердисциплінарний) і трансдисциплінарний (Т. Аугсбур, Дж. Кляйн, Л. Мітл, Д. Мос, Б. Ніколеску, Т. Осборн).

Найвідомішим для вчителя є мультидисциплінарний підхід. Він має багато спільного із традиційним навчанням і $\epsilon$, на нашу думку, перехідним між предметним та інтегрованим навчанням. Діти вивчають тему чи проблему з різних сторін, але при цьому межі навчальних предметів не порушу- 
ються. У такому контексті вчитель може проводити інтегровані уроки чи дні, викладати інтегровані навчальні курси, не «ламаючи» традиційний розклад уроків. Такі занурення учнів у тему спряють формуванню у них цілісного уявлення про світ працюють на засвоєння грунтовних предметних компетенцій. I. Большакова пропонує такі способи мультидисциплінарної інтеграції: інтеграція навчальних предметів у межах освітніх галузей, інтеграція-ф'южин (злиття), організація навчання у навчальних осередках, інтеграція паралельних дисциплін, інтеграція навчання за тематичними циклами (Коханко, 2019).

Міждисциплінарний i трансдисциплінарний підходи ефективно апробовані авторськими школами на заході та в американській системі. Звісно, вони мають своїх прибічників і критиків. Такі інтеграційні підходи передбачають стирання чітких меж та обрисів навчальних предметів. Так, міждисциплінарна інтеграція має на меті вивчення учнями теми 3 використанням знань і вмінь із різних наукових галузей. Тому вчитель 3 учнями можуть переносити методи дослідження з однієї науки в іншу, а учні засвоюють не конкретні предметні знання, а систему знань про досліджуване явище. Прикладами міждисциплінарної інтеграції $\epsilon$ інтегроване вивчення однієї теми, що включає знання 3 різних навчальних дисциплін або інтегрований навчальний курс на основі будь-якого навчального предмета.

Найскладнішим є трансдисциплінарний підхід до інтегрованого навчання. Його ми спостерігаємо у низці світових технологій вільного виховання, які відмовилися від класно-урочної системи (Вальдорфська школа, «Школи саморозвитку» М. Монтессорі, трудова школа С. Френе, «Школа Саммерхілл» О. Ніла, школа-парк). Цей підхід передбачає повне злиття навчальних дисциплін і створення єдиного освітнього середовища, в якому дитина самостійно визначає тему для дослідження. Якщо у міждисциплінарному підході ми формулюємо тему для вивчення 3 огляду на навчальні предмети, то при трансдисциплінарному підході - відштовхуємося від потреб та інтересів дитини до пошуку потрібного знання у певних наукових галузях (Nicolescu, 1999).

Розглядаючи занурення з точки зору проєктної діяльності, варто зазначити, що іiі організації і проведенню у початковій школі приділяється значна увага в сучасній освітній практиці. Аналізуючи фахову періодику, спостерігаємо наявність систематичних рубрик у виданнях, в яких висвітлюються учнівські проекти з різною тематикою, формами організації, особливостями проведення, представлення і оцінювання результатів проектів. Основними для педагогів у цьому питанні є праці вчених і практиків у таких напрямах: педагогічні та філософські аспекти проектної технології (Дж. Дьюї, У. Кілпатрик), методичні орієнтири соціально-педагогічного проектування (В. Кутьєв, Л. Філіпов); особливості становлення та розвитку загальної і проектної культури студентів і педагогів, проектування як освітня технологія, проектування програм, засобів і способів педагогічної діяльності (Н. Бібік, В. Бондар, О. Лінник, О. Пехота, О. Савченко, Г. Селевко, О. Онопрієнко, А. Цимбалару та інші вчені).

Що стосується учнівських проектів і методики їх організації, то тут доречно згадати доробок педагогів Л. Беліменко, Т. Гільберг, І. Грущинської, О. Кондратюк, С. Липки. Цінними для педагогів $\epsilon$ ідеї з методичним супроводом для організації проектної діяльності учнів із предметів і модельних тижнів, представлені в обох Типових освітніх програмах, за якими навчаються сучасні молодші школярі (О. Савченко, Р. Шиян).

Узагальнюючи існуючий досвід, доречно згадати напрями, за якими характеризують учнівські проекти: за характером домінантної діяльності у проекті (інформаційні, дослідницькі, рольові, ігрові, прикладні), за предметно-змістовою сферою інтересів (до якого предмету чи предметів відноситься проект, чи передбачений він освітньою програмою і конкретним предметом, чи створюється педагогом та учнями), за кількістю учасників у проекті (індивідуальні, фронтальні, колективні (парні, групові), за термінами виконання (короткотермінові, середньої тривалості або довготривалі); за рівнем реалізації міжпредметних зв'язків (однопредметні чи інтегровані), за формою презентації чи захисту результатів проекту (пленарні, стендові, мультимедійні, рольові); за характером залучення вчителя до виконання проектів (безпосередня координація чи прихована 3 урахуванням віку дітей) (Васютіна, 2015).

Протягом 2018-2020 років ми проводили наукове дослідження за темою «Формування основ громадянської компетентності в учнів початкової школи у процесі хвильового занурення в умоваx STREAM-освіти» у 33СО № 258 м. Києва у 2-му класі НУШ. Зупинимося детальніше на його організаційних особливостях та одержаних результатах (Хвильове, 2020).

Аналіз практики роботи у цьому державному закладі освіти показав, що занурення $є$ одним зі способів міждисциплінарної інтеграції. Вони представлені у довготривалій проєктній діяльності школярів і досить вдало поєднуються з іде- 


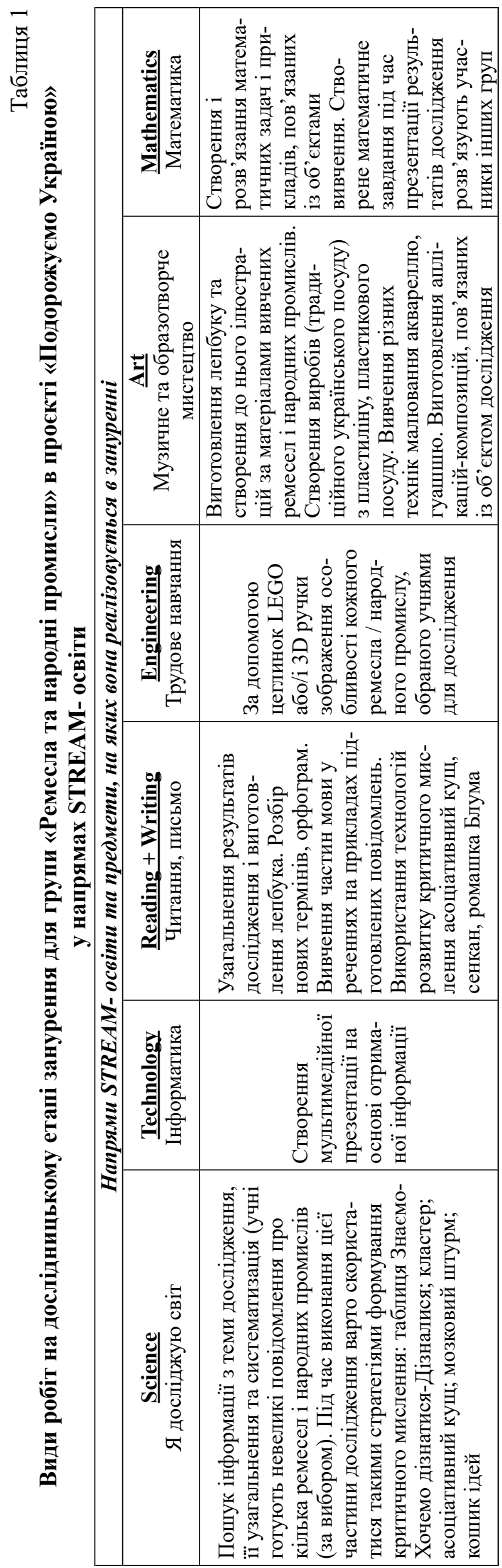

ями STREAM-освіти. При збереженні традиційного розкладу у класі і класичного предметного навчання педагоги 33СО № 258 успішно комбінують урочну і позаурочну діяльності під єдиною темою проєкту. Розподіл навчального навантаження учнів у нашому дослідженні відбувався відповідно до освітніх галузей і складників STREAMосвіти: Science (ОГ «Природнича», «Соціальна та здоров'язбережувальна» (Я досліджую світ), Technology (ОГ «Інформатична» (інформатика), Reading + Writing (ОГ «Мовно-літературна» (читання, письмо) Engineering (ОГ «Технологічна» (трудове навчання), Art (ОГ «Мистецька» (музичне та образотворче мистецтво), Mathematics (ОГ «Математична» (урок математики).

Організаційно-методичними орієнтирами в організації хвильового занурення у 2-му класі в умовах STREAM-освіти у цьому дослідженні ми виділили такі:

1) підпорядкування тематики і змісту роботи в хвилі загальношкільній науково-дослідній темі (у нашому випадку це «Підвищення якості освіти та іiі результативності шляхом формування ключових і предметних компетентностей учнів»);

2) вибір теми занурення разом із учнями, яка була б їм цікавою і водночас не надто відхилялася від календарно-тематичного планування загалом і предметів-складників STREAM-освіти зокрема;

3) узгодження діяльності класу у хвилі 3 вчителями-предметниками (інформатика, іноземна мова, музичне мистецтво) з метою корекції змісту і методики проведення їхніх уроків 3 темою занурення, що є однією з умов здійснення міждисциплінарної інтеграції;

4) розробка орієнтовного змісту, методів, форм, засобів роботи на етапах проєкту (підготовчому, дослідницькому, підсумковому) 3 урахуванням того, що занурення буде здійснюватися як під час уроків, так і в позаурочній діяльності (на ГПД, вдома, під час екскурсій, прогулянок);

5) прогнозування і підбір обладнання, яке відповідає темі роботи класу (групи) у хвильовому зануренні та предметам STREAM-освіти: інформаційних ресурсів і технічних засобів (програми Microsoft PowerPoint, Microsoft Word, точковий рисунок, Paint, 3D ручки, принтери), літературних творів (наприклад, додатково ознайомити дітей із оповіданням В. Сухомлинського, зміст якого можна інтерпретувати 3 позиції дотримання чи порушення прав дітей), атласів і карт (Я досліджую світ), творів мистецтва, конструкторів LEGO;

6) пояснення учням суті роботи у хвилі як довготривалому проєкті та іiї відмінність від зви- 
чайних уроків (активне навчання разом і в групах 3 використанням елементів релаксації, навіювання та гри; можливість вільно висловлювати своєї думки, некритичне сприйняття повідомлень 3 боку інших учасників, у яких щось стверджується або заперечується без доведення), етапів роботи над темою, підготовкою результатів, їх представленням та оцінюванням;

7) складання загальних правил роботи у проєкті-зануренні всього класу та безпосередньо у групах на кожному з ії етапів.

Для нашого дослідження ми обрали евристичну (проєктну) модель занурення і назвали іiі «Подорожуємо Україною». Відповідно до тематики ми розробили його зміст і методику, в яких були використані ідеї освітніх платформ “Living Democracy" (ілюстровані картки з правами дітей), «Критичне мислення» (О. Пометун, вправи на розвиток критичного мислення) та приклади впровадження STREAM-освіти (К. Крутій, Л. Фісунова (Освітній центр "Insight" КМДШ) (Хвильове, 2020).

Згідно із завданнями занурення учні були об’єднані в такі гетерогенні групи: «Природа України», «Видатні постаті», «Визначні пам'ятки», «Ремесла та народні промисли», «Водойми». Учасники повинні були виконувати відповідні завдання в межах предметів STREAM під час уроків та у позаурочній роботі. Важливим $€$ те, що при роботі над зануренням не порушувалася тематика і логіка викладання уроків, передбачених навчальним розкладом закладу освіти.

Наведемо приклад організації занурення «Подорожуємо Україною» у 2-му класі в таблиці 1 (Хвильове, 2020).

У процесі роботи (на прикладі програмних літературних творів, інформації природничого характеру, математичних задач) учням пропонувалися різні вправи з розвитку критичного мислення (асоціативний кущ, незакінчені речення, сенкан, кероване читання 3 передбаченням) та вправи i дидактичний матеріал 3 інструментарію DOCCU (Living Democracy) («Світове кафе», «Павутина», «Китайські палички», ілюстровані картки з правами дітей і сюжети творів, у яких ці права порушувалися (завдання подані у вигляді листів від казкових героїв, які просять про допомогу у вирішенні питання порушення їх дитячих вправ).

Як показали результати нашого дослідження, учні експериментального класу, які працювали за нашою методикою, продемонстрували вищий рівень сформованості складників громадянської компетентності, на розвиток і формування яких була спрямована робота в зануренні «Подорож Україною» (Хвильове, 2020).

Висновки. Таким чином, узагальнивши інформацію 3 різних доступних джерел і результати експериментального дослідження, можна констатувати, що занурення у початковій школі - це метод навчання, який базується на засадах психодидактики (з використанням елементів релаксації, навіювання та гри), міждисциплінарної інтеграції та довготривалої проєктної діяльності. Це складник технології концентрованого навчання, який $\epsilon$ прикладом моделі евристичного (проєктного) занурення.

Одержані результати засвідчили, що повноцінна організація занурень у початковій школі можлива за умови запровадження STREAMосвіти. Це дозволяє педагогам більш інтенсивно інтегрувати навчальний матеріал, ширше використовувати інтерактивні вправи та вправи на розвиток критичного мислення, організовувати групову роботу в межах занурень 3 учнями як під час уроків, так і в позаурочній діяльності. Цілком ймовірно, що дуже скоро і трансдисциплінарний рівень інтеграції буде під силу творчим вчителям, які не бояться «ламати» стереотипи, рамки та межі дисциплінарного навчання.

\section{СПИСОК ВИКОРИСТАНИХ ДЖЕРЕЛ}

1. Васютіна Т. М. Методичні орієнтири організації проєктної діяльності учнів з природознавства у початковій школі. Початкова школа. 2015. № 11. С. 50-54.

2. Коханко О. Г. Історичні аспекти розвитку інтегрованого підходу в освіті. Науковий часопис Національного педагогічного університету імені М. П. Драгоманова. Серія 17. Теорія і практика навчання та виховання. Випуск 30 : збірник наукових праць / за наук. ред. академіка В. І. Бондаря. Київ : Вид-во НПУ імені М. П. Драгоманова, 2019. С. 94-104.

3. Метод занурення. URL: http://elibrary.kubg.edu.ua/id/eprint/5980/3/O_Serhieienkova_IL.pdf (дата звернення: 10.09.2019).

4. Офіційний сайт КМДШ. URL: https:/www.creativeschool.com.ua/wave_of_september/\#more-11102 (дата звернення: 18.09.2020).

5. Селевко Г. К. Энциклопедия образовательных технологий: в 2 т. Т. 1. М. : НИИ школьных технологий. 2006.816 с.

6. Nicolescu B. The transdisciplinary evolution of learning. URL: http://www.learndev.org/dl/nicolescu_f.pdf (дата звернення: 04.04.2019).

7. Хвильове занурення. Золотаренко Т. О. Конкурсна робота «Формування основ громадянської компетентності в учнів початкової школи у процесі хвильового занурення в умовах STREAM-освіти». URL: http://vspu.edu.ua/content/ hot/rey/a7.pdf. 


\section{REFERENCES}

1. Vasyutina T. M. Metodychni oriyentyry orhanizatsiyi proektnoyi diyalnosti uchniv z pryrodoznavstva u pochatkoviy shkoli. [Methodical guidelines for the organization of project activities of students in science in primary school]. Elementary School. 2015. № 11. P. 50-54 [in Ukraine].

2. Kokhanko O. H. Istorychni aspekty rozvytku intehrovanoho pidkhodu v osviti. [Historical aspects of the development of an integrated approach in education]. Scientific journal of the National Pedagogical University named after M. P. Drahomanov. Series 17. Theory and practice of teaching and education. Issue 30: a collection of scientific papers / by scientific editor. Academician V. I. Bondar. Kyiv : M. P. Drahomanov National Pedagogical University Publishing House, 2019. P. 94-104 [in Ukraine].

3. Metod zanurennya. [The method of immersion]. URL: http://elibrary.kubg.edu.ua/id/eprint/5980/3/O_Serhieienkova_ IL.pdf [in Ukraine].

4. Ofitsiynyy sayt KMDSH. [Official site of KMDSh]. URL: https://www.creativeschool.com.ua/wave_of september/\#more-11102 [in Ukraine].

5. Selevko H. K. Éntsyklopedyya obrazovatelnykh tekhnolohyy: [Encyclopedia of educational technologies]: in 2 vols. Vol. 1. M. : Research Institute of School Technologies. 2006. 816 p. [in Russian].

6. Nicolescu V. The transdisciplinary evolution of learning. URL: http://www.learndev.org/dl/nicolescu_f.pdf.

7. Khvylove zanurennya. Zolotarenko T. O. Konkursna robota "Formuvannya osnov hromadyanskoyi kompetentnosti $\mathrm{v}$ uchniv pochatkovoyi shkoly u protsesi khvylovoho zanurennya v umovakh STREAM-osvity". [Wave immersion. Zolotarenko T. O. Competitive work "Formation of the foundations of civic competence in primary school students in the process of wave immersion in STREAM-education"]. URL: http://vspu.edu.ua/content/hot/rey/a7.pdf [in Ukraine]. 